\title{
ECTHR JUDGEMENTS IN THE DECISIONS OF THE HUNGARIAN CONSTITUTIONAL COURT
}

\author{
Adél KÖBLÖS ${ }^{1}$
}

The aim of this study is to explore the influence of the judgements of the European Court of Human Rights (ECtHR) on the case law of the Hungarian Constitutional Court on the basis of the analysis of thirty selected decisions. The Constitutional Court has a rather ambivalent attitude (to the references) to the ECtHR judgements. One of the approaches is that, based on the principle of pacta sunt servanda, the Constitutional Court should follow the Strasbourg case law and the level of protection of fundamental rights, even where this would not necessarily stem from its 'precedent decisions'. In other decisions one can come across with arbitrary selection of ECtHR judgments or silent disregard of the Strasbourg case law. The Constitutional Court uses the ECtHR jurisprudence in its constitutional reasoning in a quite multicoloured and flexible way. Even when the ECtHR judgements have a very loose connection with the subject matter of the case before the Constitutional Court, it is not reluctant to rely on them. However, in the so-called common cases the Court not necessarily makes much use of the relevant ECtHR judgement or it is not decisive in itself. A large body of dogmatic considerations elaborated in the Strasbourg case law has become a part of the Hungarian constitutional law, which is reaffirmed case by case by the Constitutional Court. Nevertheless, it cannot be identified precisely what weight the Constitutional Court attributes to the ECtHR judgments.

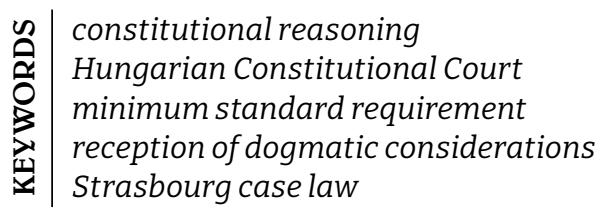

\section{Introduction}

The aim of this study is to explore the influence of the judgements of the European Court of Human Rights (ECtHR) on the case law of the Hungarian Constitutional Court.

1 | Senior Research Fellow, National University of Public Service in Budapest, Hungary, koblos. adel@uni-nke.hu. 
The examination is based on the analysis of 30 decisions ${ }^{2}$ of the Hungarian Constitutional Court selected for the purposes of the research project 'Interpretation of fundamental rights in Europe' carried out within the framework of the Central European Professors' Network coordinated by the Mádl Institution of Comparative Law, the Hungarian Association for Comparative Law, and the Central European Association for Comparative Law. The analysis is not suitable for providing a comprehensive picture of the effect of the case law of the ECtHR because of the selection criteria. ${ }^{3}$ One of them was that each decision should contain a relevant/substantive reference to a judgement of the ECtHR; therefore, decisions without an explicit reference remained outside the scope of this research. Although one might think that the examination of decisions without such a reference would not add too much to the overall picture, it is worth mentioning Justice Pokol's concurring reasoning to Decision 3025/2014. (II. 17.) of the Constitutional Court ${ }^{4}$. He proposed to present the relevant ECtHR case law in the draft decision for in-house use only (pro domo) instead of including references in the final reasoning. ${ }^{5}$ This way of thinking is not alien to other bodies either, i.e. the French Conseil constitutionnel traditionally avoided express

2 | Decision 38/2012. (XI. 14.) of the Constitutional Court, Decision 1/2013. (I. 7.) of the Constitutional Court, Decision 3/2013. (II. 14.) of the Constitutional Court, Decision 4/2013. (II. 21.) of the Constitutional Court, Decision 16/2013. (VI 20.) of the Constitutional Court, Decision 33/2013. (XI. 22.) of the Constitutional Court, Decision 7/2014. (III. 7.) of the Constitutional Court, Decision 3025/2014. (II. 17.) of the Constitutional Court, Decision 20/2014. (VII. 3.) of the Constitutional Court, Decision 28/2014. (IX. 29.) of the Constitutional Court, Decision 36/2014. (XII. 18.) of the Constitutional Court, Decision 24/2015. (VII. 7.) of the Constitutional Court, Decision 30/2015. (X. 15.) of the Constitutional Court, Decision 5/2016. (III. 1.) of the Constitutional Court, Decision 3064/2016. (IV. 11.) of the Constitutional Court, Decision 13/2016. (VII. 18.) of the Constitutional Court, Decision 14/2016. (VII.18.) of the Constitutional Court, Decision 16/2016. (X. 20.) of the Constitutional Court, Decision 22/2016. (XII. 5.) of the Constitutional Court, Decision 2/2017. (II. 10.) of the Constitutional Court, Decision 8/2017. (IV. 18.) of the Constitutional Court, Decision 28/2017. (X. 25.) of the Constitutional Court, Decision 29/2017. (X. 31.) of the Constitutional Court, Decision 34/2017. (XII. 11.) of the Constitutional Court, Decision 6/2018. (VI. 27.) of the Constitutional Court, Decision 1/2019. (II. 3.) of the Constitutional Court, Decision 2/2019. (III. 5.) of the Constitutional Court, Decision 7/2019. (III. 22.) of the Constitutional Court, Decision 13/2019. (IV. 8.) of the Constitutional Court, Decision 13/2020. (VI. 22.) of the Constitutional Court.

3 | A criterion was that the selected cases had to be 'important' ones and that they had to be from the last 10 years (2011-2020), i.e. the decision in the given case was made in this period. I selected decisions dating back to 2012, as the Fundamental Law came into effect in this year. A further criterion was that each decision contained a substantive reference to ECJ or ECtHR decisions. I selected decisions with relevant reference to ECtHR judgments; nevertheless, one can also find references to ECJ judgments in some of the selected decisions.

4 | Repeated in concurring reasoning to Decision 8/2017. (IV. 18.) of the Constitutional Court, dissenting opinion to Decision 1/2019. (II. 13.) of the Constitutional Court, concurring reasoning to Decision 7/2019. (III. 22.) of the Constitutional Court, and concurring reasoning to Decision 13/2019. (IV. 8.) of the Constitutional Court.

5 | 'Relevant decisions of the ECtHR may play a useful role in our draft decisions as information in the constitutional court decision-making process, for internal use, but in my opinion they should not be included in the final decision, at most in individual parallel and dissenting opinions as further arguments of individual constitutional judge positions. The reference in the decision of the Constitutional Court means that, in addition to the Basic Law, we attribute normative, binding force not only to the Convention but also to the judicial practice interpreting it, thus recognizing that the ECtHR may rewrite the international obligations binding on them without the participation of States parties.' He insists that the case law of the ECtHR is not binding on the Constitutional Court in interpreting fundamental rights. 
references to the ECtHR judgements; however, it used 'borrowing techniques' and, in some cases, the sources of reasoning can be traced back to the case law of the Strasbourg Court $^{6}$. Despite the lack of express reference to the ECtHR judgements, the Constitutional Court/the justice rapporteur wording the ruling and wording the reasoning may consider and rely on them. This approach can obscure the real basis of the reasons, which is contrary to what was said in Decision 13/2013. (VI. 17.) of the Constitutional Court by invoking the rule of law principle: 'the reasoning and the sources of constitutional law must be accessible and verifiable for everyone, and the need for legal certainty requires that the considerations in decision-making be transparent and traceable'.

I have already pointed out in my study 'Interpretation of Fundamental Right is Hungary'7 on the basis of the analysis of the selected decisions that the Constitutional Court has a rather ambivalent attitude (to the references) to the ECtHR judgements. One cannot be sure of the role the ECtHR jurisprudence of the plays in the constitutional reasoning of the Hungarian forum; the ECtHR judgements appear in various contexts and perform different functions. In the present study, first, I present the opposing approaches: the one in favour of and the other against using references to the European case law and, subsequently, make an attempt to explore how these affect the constitutional reasoning of the Constitutional Court in particular cases. I take a closer look at the substance of the reasoning of the selected decisions to determine, as far as possible, the real impact of the ECtHR judgements on the Hungarian Constitutional Court.

\section{History and approaches}

Szente points out that while the source of reception was concentrated mainly around the German case law (Bundesverfassungsgericht) and that of the US Supreme Court at the beginning of the functioning of the Constitutional Court (in the1990s), since the 2000s the 'legal import' has shifted to the ECtHR judgements and the alignment with these judgements has become the trend rather than participating in an international constitutional law dialogue. ${ }^{8}$ According to him, this is partly explained by the particularities of the early area. Justice Sólyom, president of the Constitutional Court from 1990 to 1998, and some other influential justices in the body were known for their 'German orientation'. Jakab and Fröhlich also highlight that talented constitutional lawyers spent several months or years in Germany (at universities or the Max Plank Institute for Comparative Public Law and International Law in Heidelberg), thanks to the generous German scholarship policy. Those who got a position at the Constitutional Court as a judge or an advisor to a judge later implemented what they had experienced in Germany. ${ }^{9}$ The Court adopted reasoning from decisions of the German Federal Constitutional Court quite frequently even without any reference to the source thereof. The large-scale reception of the foreign arguments was understandable in a country that had no tradition of constitutional democracy and

6 | Kovács, 2013, p. 83.

7| Köblös, 2021, p. 204.

8| Szente, 2013a, p. 54.

9 | Jakab-Fröhlich, 2017, p. 426. 
protection of human rights. ${ }^{10}$ After about 10 years, a Hungarian body of constitutional law was elaborated; therefore, it was not necessary to rely on foreign sources so much and the reference to its own precedents became the rule. ${ }^{11}$ The composition of the Constitutional Court also changed; the new president and members brought in new approaches concerning methods of interpretation, including more frequent references to the ECtHR judgements.

In 2010, the governing party coalition gained a two-thirds majority in the Parliament, which opened the way towards making a new constitution. Even before passing the Fundamental Law, the previous Constitution was amended with the clear purpose of restricting the power of the Court ${ }^{12}$, derogate from its previous case law, ${ }^{13}$ and affect its composition by increasing the number of members from 11 to 15 . The Fundamental Law also introduced new rules, and the parliamentary majority adopted unusual solutions (see: transitional provisions of the Fundamental Law ${ }^{14}$ ). In those circumstances, the Constitutional Court's attention was much more drawn to international law.

In Decision 61/2011. (VII. 13.) of the Constitutional Court, the Court argued that the Hungarian Constitution had immutable parts based on the principles included in international treaties. The immutability is based not on the will of the constitutional power, but mostly on ius cogens and the international treaties to which the Republic of Hungary was a party. The coherence of the principles enshrined in international treaties and the national constitutional systems should be ensured. The internal law of the state-if it had any obligations in the given field of law deriving from customary or even contractual international law-should be made and interpreted in accordance with those obligations. For certain fundamental rights, the Constitution defines the essence of the fundamental rights in the same way as an international treaty (the Covenant on Civil and Political Rights and the Human Rights, European Convention on Human Rights). In these cases, the level of protection of fundamental rights provided by the Constitutional Court cannot be lower than the international (typically by the Strasbourg Court of Human Rights) level of legal protection. Based on the principle of pacta sunt servanda [Section 7(1) of the Constitution, Art. Q (2)-(3) of the Fundamental Law consequently], the Constitutional Court should follow the Strasbourg case law and the level of protection of fundamental rights, even where this would not necessarily stem from its 'precedent decisions'. There were no concurring reasoning or dissenting opinions attached to this decision, opposing this argumentation.

In the same year, another decision ${ }^{15}$ was made in which the Constitutional Court annulled several provisions of the Code of Criminal Procedure, finding them contrary to the Constitution and an international treaty, namely the ECHR. The composition of the Court had changed by then, and the number of members of the Court had increased to 15. The reasoning was strongly based on the case law of the ECtHR; the reasons underpinning the unconstitutionality and those verifying the infringement of the ECHR

10 | Szente, 2013a, p. 235.

11 | Jakab-Fröhlich, 2017, p. 411.

12 | Act CXIX of 2010

13 | Modification of the Constitution of 11 August 2010, Act LXI of 2011

14 | See Decision 45/2012. (XII. 29.) of the Constitutional Court annulling several provisions of the transitional provisions of the Fundamental Law.

15 | Decision 166/2011. (XII. 20.) of the Constitutional Court. 
were not separated. The Court emphasised that the meaning and interpretation of the provisions included in the ECHR, in accordance with its case law, are based on the ECtHR jurisprudence empowered by the contracting states with authentic interpretation. Two justices objected to the logic of reasoning and to relying on the precedents of the ECtHR in interpreting the Constitution; only one of them was a newly elected member of the Court. The other, Justice Bragyova, raised dogmatic objections to the solution chosen by the majority, arguing that the Constitutional Court was not bound by the ECHR in substantive constitutional law issues. Consequently, the Court could not have established its argumentation and the interpretation of the Constitution on the ECtHR's case law. This could be an important inspiration in the interpretation of the Constitution, but this jurisprudence was not binding on the Constitutional Court and not as decisive as the Constitutional Court's own precedents. Justice Bragyova also pointed out that this approach did not deny the outstanding significance of the ECtHR's judgements in the interpretation of the Constitution. He found it necessary to consider the ECtHR jurisprudence to verify the pertinence of the constitutional interpretation. If the Constitutional Court and ECtHR reached different constitutional conclusions, the Constitutional Court should reconsider those conclusions, but it was not obliged to follow the case law of the ECtHR. Justice Dienes-Oehm, a newly elected judge, joined Justice Bragyova's concurring reasoning.

After the Fundamental Law had come into effect, the above-mentioned requirements elaborated in Decision 61/2011. (VII. 13.) of the Constitutional Court were taken over from the 'old' case law. ${ }^{16}$ In Decision 32/2012. (VII. 4.) of the Constitutional Court, it was used with respect to EU law. ${ }^{17}$ In Decision 4/2013. (II. 21.) of the Constitutional Court, the Court emphasises that although the ECtHR judgements have a declarative effect ${ }^{18}$, its case law can help in the interpretation of constitutional rights declared in the Fundamental Law or international treaties and in the assessment of their scope and content. As the essence of the fundamental rights is embodied in judgements given in particular cases, the European jurisprudence promotes the uniform interpretation of human rights. The Court further added that respecting the ECtHR case law may not lead to the limitation of fundamental rights guaranteed by the Fundamental Law or to a lower level of protection. The Strasbourg case law and the Convention provide for a minimum level of fundamental rights protection that every state party to the Convention is bound to guarantee, while the national law might foresee a different, higher set of requirements for the protection of human rights.

In Decision 7/2013. (III. 1.) of the Constitutional Court, it reaffirmed that for certain fundamental rights, the Constitution defines their essence in a way similar to that of an international treaty (the Covenant on Civil and Political Rights and the Human Rights, European Convention on Human Rights). In these cases, the level of protection of fundamental rights provided by the Constitutional Court cannot be lower than

16 | See in details: Chronowsk, 2014, p. 30-32.

17 | In relation to the right to choose work and employment freely, the Constitutional Court emphasised that the Court may not ignore the relevant rules of the European Union and the jurisprudence of the ECJ. Confirming the standard elaborated in Decision 61/2011. (VII. 13.) of the Constitutional Court, the Court pointed out that it [i.e. the level of protection of fundamental rights provided by the Constitutional Court cannot be lower than the international (typically by the Strasbourg Court of Human Rights) level of legal protection] is especially true in relation to the law of the European Union.

18 It means that they cannot alter legal questions directly. 
the international (typically by the Strasbourg Court of Human Rights) level of legal protection. ${ }^{19}$

In Decision 36/2013. (XII. 5.) of the Constitutional Court, the Court used the abovementioned requirement to explain why it initiated an examination of conflicts with international treaties ex officio. In Decision 13/2014. (IV. 18.) of the Constitutional Court, the Court slightly reworded the requirement: the Constitutional Court accepts the level of legal protection provided by international legal protection mechanisms as the minimum standard for the enforcement of fundamental rights.

Eight out of the 30 decisions refer to the above-mentioned minimum requirements [i.e. the level of protection of fundamental rights provided by the Constitutional Court cannot be lower than the international level of legal protection] in one way or another. ${ }^{20}$

Despite the reaffirmation, reference to international agreements and the case law of the ECtHR has not become a standard and indispensable element of the reasoning of the decisions. In particular, if a case can be easily solved on the basis of the Constitutional Court's own precedents, the Court does not spend time and energy on exploring and presenting relevant ECtHR jurisprudence. It is worth mentioning, furthermore, that Justice Kovács judge rapporteur of Decision 166/2011. (XII. 20.) and 33/2013. (XI. 22.) of the Constitutional Court, remained in minority in some cases with his opinion referring to this requirement. ${ }^{21}$

Although there has been a significant change in the composition of the Court [i.e. all judges who participated in delivering Decision 61/2011. (VII. 13.) have already left the Court] and there are justices heavily opposing the references to the ECtHR judgements, the 'minimum standard' requirement has not yet disappeared from the case law. The ambivalent attitude of the Constitutional Court with respect to the role of the European jurisprudence might be explained by the fact that some members of the body still question the correctness of the 'minimum standard' requirement or disagree with any reference to the ECtHR judgement.

Justice Pokol has become the advocate of questioning the relevance of the ECtHR's case law in the interpretation of the Fundamental Law. His standpoint is much harsher than that of Justice Bragyova and supported partly by dogmatic/theoretical considerations and partly by foreign sources of legal literature ${ }^{22}$. He maintains that the ECtHR decisions are not drawn up by competent judicial councils on the basis of the European Convention on Human Rights but by an about 300-member human rights apparatus developed over the years, with the most basic lack of independence of judges. In his dissenting opinion to Decision 1/2019. (II.13.) of the Constitutional Court, he argued in favour

$19 \mid$ See also Decision 8/2013. (III. 1.) of the Constitutional Court.

20 | Decisions 4/2013 (II. 21.) [judge rapporteur: Justice Lévay), 33/2013. (XI. 22.) [judge rapporteur: Justice Balsai], 7/2014. (III. 7.) [judge rapporteur: Justice Paczolay], 3025/2014. (II. 17.) [judge rapporteur: Justice Szívós], 30/2015. (X. 15.) [judge rapporteur: Justice Sulyok, 8/2017. (IV. 18.) [judge rapporteur: Justice Szívós], 13/2019. (IV. 8.) [judge rapporteur: Justice Hörcherné Marosi], 13/2020. (VI. 22.) of the Constitutional Court [judge rapporteur: Justice Hörcherné Marosi]

21 | Justice Kovács's concurring reasoning to Decision 1/2013. (I. 7.) of the Constitutional Court and dissenting opinion to Decision 16/2013. (VI. 20.) of the Constitutional Court.

22 | He referred to an interview with a former justice of the ECtHR, David Thór Björgvinss, on criticising the Court [Utrecht Journal of International and European Law (Vol. 81.) 2015. No.31] and a study from Matilde Cohen (Judges or Hostages? In: Nicola/Davies eds.: EU Law Stories. Cambridge University Press 2017, 58-80.) 
of looking at the ECtHR judgements as simple legal opinions without authenticity, or as a source of information. He also suggested presenting the relevant case law of the ECtHR in the draft decision only for in-house use (pro domo).

Ideological and theoretical considerations, such as the rejection of the universal claim to constitutional rights ${ }^{23}$, priority of majority democracy and state sovereignty ${ }^{24}$, different conceptions of how the Fundamental Law is embedded in the European and international law, personal commitments, and judicial role perception ${ }^{25}$, also contribute to this controversial situation. It is not yet clear how the ECtHR judgements can fit into the national legal system, and what sort of binding effect they might have on the national judicial and other organs. ${ }^{26}$

To avoid superfluous debates in the competent body (plenary session or the council of five members), the draft and final decision might disguise the real role of the jurisprudence of the international court in the interpretation of the Fundamental Law.

\section{References to the ECtHR judgements}

The 'minimum standard' requirement is a relatively clear revelation of what role the Constitutional Court attributes to the ECtHR case law in its own constitutional reasoning. Nevertheless, not all selected decisions make use of this approach. In some cases, it has a logical explanation. For example, as will be discussed in detail below, the Constitutional Court makes references to the European case law even when the examination is carried out on the basis of the provisions of the Fundamental Law which do not embody human rights. In other cases, however, the statements of reasons are unfortunately not worded clearly enough to be able to explore the impact of the ECtHR judgements.

Hereinafter, I would like to outline how and in what context the Constitutional Court refers to the judgements of the European forum, beyond the above-mentioned 'minimum standard' requirement, what phrases it uses in doing so, and how much the wording of the statements of reasons facilitates the exploration of the real role of the ECtHR case law in Hungarian constitutional reasoning.

The analysis shows that the Hungarian Constitutional Court does not contrast different views in its decisions; it prefers drawing arguments from various sources pointing in the same direction and strengthening the resolution chosen to rebut weakening arguments. This might be explained, among others, by the one-sided character of the procedure before the Constitutional Court, since there are no opposing parties offering alternative solutions and argumentations to the Court. This kind of technique contributes towards hiding the importance and decisive/defining/confirming/illustrative features of the various methods of interpretation.

23 | Kovács, 2020, p. 149.

24 I Justice Pokol's main dogmatic argument against the primacy of international law stems from the principle of popular sovereignty [see his concurring reasoning to Decision 12/2013. (V. 24.) of the Constitutional Court]. Uitz, 2016, p. 179.

25 | Uitz, 2016, p. 179.

26 | See in details: Uitz, 2016, p. 187. 
In a group of the selected decisions, the Court-with or without a reference to the obligation of Hungary to ensure coherence between international law and domestic law-sums up the relevant ECtHR jurisprudence in a separate section and states that the Court has taken it into account. The European case law appears among other methods of interpretation-especially, the reference to previous decisions of the Constitutional Court-but other methods are also used quite often, such as reference to other international treaties, jurisprudence of foreign courts, opinions or recommendations of the Venice Commission, etc. ${ }^{27}$ Another similar, frequently used structure of argumentation is when various methods appear mixed in the reasoning and the Court uses the term 'takes (them) into account'. One might also come across other phrases in relation to the ECtHR's case law; e.g.: the Constitutional Court 'evaluated' 28 , 'see similarly'29, 'this view is supported by'30, and this is 'in line with'. Neither of these words reveals the real impact of the ECtHR judgements on the Constitutional Court's decisions; nevertheless, they show that the domestic case law is in harmony with the European 'trends'. Therefore, they at least have a confirming function.

In other decisions, the Constitutional Court-apparently-does not avail itself of the European jurisprudence; it only 'overviews' or 'examines' it. ${ }^{31}$ Only a deeper analysis of the substance of the cases and the whole contents of the reasoning can bring us closer to the actual role of this 'examination'.

Beyond the above-mentioned 'minimum standard' requirement, it is rather rare when the Constitutional Court provides more or less precise guidance on what weight it attributes to the European case law. In Decision 1/2013. (I. 7.) of the Constitutional Court, the Court maintained that the ECtHR judgement was a 'guideline'. ${ }^{32}$ Quoting at length from the judgement delivered in the case of the Georgian Labour Party v Georgia ${ }^{33}$ with respect to the voter registration on request, it stated that under Art. 3 of Protocol No. 1, linking the exercise of the right to vote to active registration restricts the right to free elections. The ECtHR, contrary to the Constitutional Court, did not find a violation of the fundamental right; therefore, the final outcome of the Georgian Labour Party case was irrelevant from the Constitutional Court's perspective. In another decision, ${ }^{34}$ the Court said that it relied primarily on its own previous case law, while in a certain aspect, ${ }^{35}$ it "paid special attention to' that of the ECtHR. Reading the whole argumentation, one can conclude that concerning the subject matter where ECtHR judgements were invoked, there had been no specific precedent of the Constitutional Court available, while there was such a European case

27 | Decisions 7/2014. (III. 7.), 33/2013. (XI. 22.), 1/2013. (I. 7.) of the Constitutional Court.

$28 \mid$ Decision 8/2017. (IV.18.) of the Constitutional Court

29 | Decision 3/2013. (II.14.) of the Constitutional Court

30 | Decision 3/2013. (II. 14.) of the Constitutional Court

31 | E.g. Decisions 7/2019. (II. 22.) and 5/2016. (III. 1.) of the Constitutional Court.

32 | The Court did not mention the 'minimum standard' requirement but, citing a decision from 1993 and referring to Article Q) (2) of the Fundamental Law, it emphasised the obligation to ensure that Hungarian law is in conformity with international law.

33 | Application no. 9103/04, judgement of 8 October 2008

34 | Decision 34/2017. (XII.11.) of the Constitutional Court

35 | The question was whether the press, conveying one's statements of facts infringing others' rights, can be exempted from the obligation to control the validity of those statements before publication and, if so, under what conditions. References made to the cases Jersild v Denmark (Application no. 15890/89, judgement of 23 September 1994) and Bladet v Norway (Bladet Troms $\varnothing v$ Norway, Application no. 21980/93, judgement of 20 May 1999). 
law. It also occurs that the Court refers to the ECtHR case law by citing its own previous decision (quotation in quotation). ${ }^{36}$ Since there is no doubt about the primary and decisive role of the Court's own case law, this method of reference can be seen as a way of dispelling doubts about the applicability of the argumentation of the ECtHR.

\section{The impact of the ECtHR case law on the constitutional reasoning}

In this part of the study, I attempt to shed light on the substantive effect of the European judgements referred to in the selected decisions.

\subsection{Hungarian cases}

The analysis focuses first on decisions in which the ECtHR judgement referred to was delivered in a Hungarian case. Within these decisions, one can identify the so-called common cases, where the same judicial decision or statutory law (etc.) was examined by the Constitutional Court and the Strasbourg Court. These judgements, on the one hand, may be of great assistance to the Constitutional Court, given the fact that a 'constitutional' examination is already available in relation to a Hungarian legal act (i.e. court decision, act of Parliament, decree of Government, etc.). On the other hand, if the Constitutional Court takes a different position from that of the ECtHR, it might lead to a straight-out confrontation with the ECtHR case law.

\subsubsection{Common cases}

In Decision 4/2013. (II. 21.) of the Constitutional Court, the Court annulled the challenged provision of the Criminal Code (titled: The use of totalitarian symbols ${ }^{37}$ ) despite having declared the same rule as consistent with the Constitution in an earlier decision (dated to 2000), ${ }^{38}$ not violating the prohibition of discrimination and the freedom of expression. The Constitutional Court considered in both decisions the judgement delivered in the case of Rekvényi v Hungary, ${ }^{39}$ where the ECtHR-assessing whether the particular circumstances of the particular case satisfied the requirement of "pressing social need' in a democratic society-emphasised the relevance of the specific historical background of the respondent state (Hungary was ruled by one political party between 1949 and 1989; membership of that party was, in many social spheres, expected as a manifestation of the individual's commitment to the regime; this expectation was even more pronounced within the military and police, where party membership on the part

36 | E.g. Decisions 14/2016. (VII. 18.) and 24/2015. (VII. 7.) of the Constitutional Court.

$37 \mid$ '(1) A person who (a) disseminates, (b) uses in public, or (c) exhibits a swastika, an SS-badge, an arrow-cross, a symbol of the sickle and hammer or a red star, or a symbol depicting any of them, commits a misdemeanour-unless a more serious crime is committed-and shall be sentenced to a criminal fine (pénzbüntetés). (2) The conduct proscribed under paragraph 1 is not punishable, if it is done for the purposes of education, science, art or in order to provide information about history or contemporary events. (3) Paragraphs 1 and 2 do not apply to the insignia of States which are in force.' $38 \mid$ Decision 14/2000. (V.12.) of the Constitutional Court.

39 | No. 25390/94, judgement of 20 May 1999. 
of the vast majority of serving staff guaranteed that the ruling party's political will was directly implemented). Nevertheless, later on, in the case of Vajnai v Hungary, ${ }^{40}$ the ECtHR relied again on the 'history' of Hungary and stressed that almost two decades had elapsed since Hungary's transition to pluralism, and the country had proved to be a stable democracy and become a Member State of the European Union, after its full integration into the value system of the Council of Europe and the Convention. There was no evidence to suggest that there was a real and present danger of any political movement or party restoring the communist dictatorship. In Decision 4/2013. (II. 21.) of the Constitutional Court, the Court found these arguments as legally significant new circumstances to reassess the constitutionality of the same criminal provision and it did not terminate the procedure because of so-called 'res iudicata'. ${ }^{41}$ The examination of the statutory rule was carried out primarily on the basis of the rule of law principle ${ }^{42}$ and the principle of constitutional criminal law. The violation of the freedom of expression derived solely in line with the unclear wording of the criminal provision; the fundamental limitation test was not applied. Thus, in substance, the Court did not make much use of the new approach of the ECtHR.$^{43}$ Nevertheless, it emphasised that an ECtHR judgement has a direct effect only after the delivery of the final judgement in a particular case, in a revision law procedure. Therefore, domestic courts shall apply Hungarian laws first, even in cases with the same facts as in the Rekvényi case. This aggravates the controversial character of the situation.

Decision 29/2017. (X. 31.) of the Constitutional Court deserves particular attention because the Constitutional Court was asked to examine not only the conformity of the challenged statutory provision with the Fundamental Law but also with the ECHR. A posterior norm control procedure instituted by the Commissioner for Fundamental Rights, several judicial initiatives, and a constitutional complaint procedure were joined by the Constitutional Court. The judicial initiatives were filed with the Constitutional Court after the delivery of the judgement by the Chamber of the ECtHR in the Fábián v Hungary ${ }^{44}$ case and claimed that the impugned statutory rules violated not only the right to property and prohibition of discrimination as guaranteed by the Fundamental Law but also the right to property as guaranteed by Protocol No. 1 to the ECHR. Under the challenged provision, the disbursement of those old-age pensions whose beneficiaries were simultaneously employed in certain categories within the civil service would be suspended from 1 July 2013 onwards for the duration of their employment. No such restriction was put in place

40 | Vajnai v Hungary, No. 33629/06, judgement of 8 July 2008.

41 | Article 31(1) of the Constitutional Court Act: 'If the Constitutional Court has already ruled on the conformity of an applied legal regulation or a provision thereof with the Fundamental Law based on a constitutional complaint or judicial initiative, no constitutional complaint or judicial initiative aimed to declare a conflict with the Fundamental Law may be admitted regarding the same legal regulation or provision thereof and the same right guaranteed by the Fundamental Law, with reference to the same constitutional law context-unless the circumstances have changed fundamentally in the meantime.'

42 | The reasoning is based on the concept of constitutional criminal law which is partly composed of the principle of the rule of law (as the form) and partly of the conditions for the restriction of fundamental rights (as the content). The Court presented that the unclear wording of the criminal provision had led to controversial judicial jurisprudence.

43 | See Sándor, 2020b, p. 30.

44 | Fábián v Hungary, Application no. 78117/13, judgement of 5 September 2017 
with respect to those who were in receipt of an old-age pension while being employed in the private sector. In its judgement, the Chamber first examined the applicant's complaint under Art. 14 of the Convention taken in conjunction with Art. 1 of Protocol No. 1. Having found a violation in that respect, the Chamber considered that it was not necessary to examine whether the facts of the case also constituted a violation of Art. 1 of Protocol No. 1 taken alone. The government requested the referral of the case to the Grand Chamber in accordance with Art. 43 of the Convention, and the Grand Chamber granted this request. Subsequently, the Constitutional Court suspended its procedure until the delivery of the final judgement. The Grand Chamber held that there had been no violation of Art. 1 of Protocol No. 1 taken alone, and there had been no violation of Art. 14 of the Convention taken in conjunction with Art. 1 of Protocol No. 1.

In its decision, the Constitutional Court found all petitions unfounded.

In relation to the conformity with the Fundamental Law, there is no reference to the Grand Chamber's judgement given in Fábián v Hungary or any other judgement of the ECtHR, and the 'minimum standard' requirement is not mentioned at all. As a comparative method of interpretation, the Court cited the rulings of the German Constitutional Court and emphasised that the German case law always had an important influence on Hungarian constitutional justice. The Court also cited its own case law and took into account other provisions of the Fundamental Law. Despite formally disregarding the Grand Chamber's judgement, the reasoning 'borrowed' some arguments therefrom. The most telling sign of this is that the Court introduced the test of reasonability in relation to public interest as a constitutionally acceptable object of the limitation of the right to property. This test did not appear in the Hungarian constitutional jurisprudence until this decision of the Constitutional Court. ${ }^{45}$ The Court put it as follows: in assessing whether a restriction on property rights had a legitimate aim, the State enjoys the freedom to judge what is in the public interest. It is also up to the evaluation of the legislator whether the restriction of the right to property is necessary for the enforcement of public interest. However, the legislator's assessment in this respect is not entirely free: the line is drawn where there is clearly no reasonable basis for action in the public interest. ${ }^{46}$ Focusing on the principle of social solidarity was presumably inspired also by the European judgement.

As far as the examination of conflicts with the ECHR is concerned, the Constitutional Court presented the Grand Chamber's judgement, including its reasoning, which declared that, on the one hand, the ECtHR did not find the suspension of the disbursement of the retirement pensions violating the ECHR in an individual case, and, on the other hand, the reasoning of this judgement did not fundamentally depart from the interpretation given by the Constitutional Court in its examination of the conflict with the Fundamental Law.

45 | Téglási, András pointed out that the Constitutional Court-in accordance with the generally accepted principles of international practice-accepted the existence of public interest without any further investigation. Téglási, 2011, p. 199. In his study published in 2012, he stated that the concept of public interest is rather broad and general and without a more precise definition, it may imply hidden private interests. He suggested a stricter constitutional test of public interest. (Téglási, 2012, p. 125.) The test of reasonability did not appear, for e. g. in Decision 20/2014. (VII. 3.) of the Constitutional Court, where dissenting reasons dealt in great details with the issue of the acceptability of goals as public interest. See Justice Bragyova's and Justice Kiss's dissenting opinions.

46 | See citations from the judgement in Béláné Nagy (Béláné Nagy v Hungary [GC], no. 53080/13, ECHR 2016) in the Fábián judgement. (§ 65) 
Therefore, even in this respect, the ECtHR judgement was not decisive in itself. ${ }^{47}$ This corresponds to what Bragyova explained in his study: national constitutional courts usually reserve the right to interpret the ECHR for themselves. ${ }^{48}$

Although the analysis of the two decisions provides useful information, they cannot provide a general picture of the impact of the ECtHR's case law on the interpretation of the Fundamental Law. Sándor Lénárd, on the basis of 25 cases, gives a comparative analysis of the orientation effect of the rulings of the two courts given in 'common cases'. ${ }^{49}$ The author argues that in the same fundamental rights investigations, the Constitutional Court, acting later, did not deviate from the ECtHR's criteria on limiting fundamental rights in any case, which is in line with the requirement resulting from Art. Q) of the Fundamental Law. One of his conclusions is that the ECtHR acting later in time deviated from the previous ruling of the Constitutional Court more frequently, both as a result of the rulings and criteria for limitation for fundamental rights than the Constitutional Court does from the previous ECtHR judgement. ${ }^{50}$

\subsubsection{Decisions relating to the freedom of expression}

Freedom of expression is one of the fundamental rights with respect to which the Constitutional Court often refers to the case law of the ECtHR. Two of those decisions, among the 30 selected ones, examine criminal statutory law. One of them [Decision 4/2013. (II. 21.) of the Constitutional Court] has been dealt with above.

A few months later, in another decision [Decision 16/2013 (VI. 20.) of the Constitutional Court] dealing with the constitutionality of another but very similar criminal provision of the Criminal Code (titled criminal offence of public denial of the sins of the National Socialist or Communist regimes), the Court made a reference exclusively to the Rekvényi case to support its allegation that the ECtHR, assessing the purpose and necessity of the restriction of the freedom of expression, considers the respondent state's specific historical background and present. It remained silent as for the further development in the European case law. It was highlighted only in Justice Kovács's dissenting opinion. This decision shows the arbitrary selection of the ECtHR judgements by the Constitutional Court.

\subsubsection{Reasonable time}

Staying in the criminal matters, Decision 2/2017 (II. 10.) of the Constitutional Court is an example of the special adoption of the ECtHR case law. It is a longstanding problem of the Hungarian criminal justice that procedures violate the right to a fair trial, as they are not concluded within a reasonable time. Hundreds of applications have already landed before the European forum; therefore, there is a rich jurisprudence in Hungarian cases. The procedure before the Constitutional Court-in which the above-mentioned decision was made-was initiated with a constitutional complaint filed against a judicial decision. The Constitutional Court confirmed its previous case law, saying that it was not provided with effective means to repair the violation of the fundamental right deriving from the

47 | Sándor Lénárd considers this case as an example of dialogue between the Hungarian Constitutional Court and the ECtHR promoting the delivery of decisions with the same conclusion. Sándor, 2020 a, p. 32.

48 | Bragyova, 2011, p. 83.

49 | Sándor, 2020a, p. 34.

50 | Sándor, 2020a, p. 36. 
excessive length of procedure. ${ }^{51}$ However, the Constitutional Court was aware of the ECtHR case law regarding Art. 34 of the ECHR. If the national court acknowledged the duration of the proceedings and held that the excessive protraction of the case was a crucial mitigating factor, the ECtHR would find whether the applicant obtained adequate redress for the alleged violation of their right under Art. $6 \S 1$ of the Convention to the determination within a reasonable time of the criminal charges against them. Accordingly, the applicant can no longer claim to be a victim of a violation of Art. $6 \S 1$ for the purposes of Art. 34 of the Convention. For obscure ${ }^{52}$ reasons, the Constitutional Court applied Section $28(1)^{53}$ of the Constitutional Court Act and moved on to the examination of the law applied in the criminal procedure (i.e. provision of the Criminal Procedure Act on the statements of reasons in judicial judgements). Although the base of the examination remained in the field of fair trial, it shifted to adequate reasoning for judgements which were not relied on by the complainant. Admitting the suitability of the mitigation of the sentence to remedy the violation of the right to fair trial, the Constitutional Court stipulated as a constitutional requirement that the court must state in its reasoning the fact that the proceedings were prolonged and, in this context, the mitigation of the sentence and the extent of the mitigation. Despite the fact that the ECtHR assesses whether appropriate redress has been granted in the national legal system in the scope of admissibility of the application (i.e. Art. 34 of ECHR), the Constitutional Court's decision has led to shifting this circumstance into the examination of the merits and finally resulted in a constitutional requirement in relation to proper reasoning. In the specific case, it found that there was no unconstitutionality in the reduction of the sentence, due to the excessive delay in the proceedings.

\subsubsection{Freedom of assembly cases}

Another fundamental right in relation to which the Constitutional Court likes availing itself of the ECtHR case law is the freedom of assembly. Three selected decisions ${ }^{54}$ contain reference to a particular judgement of the ECtHR made in Hungarian cases ${ }^{55}$. In one of them, the Constitutional Court pointed out that after the case of Bukta and others v Hungary, ${ }^{56}$ the Court concluded that spontaneous peaceful assemblies were included in the right of assembly, thus expressly admitting the direct impact of the European case law on Hungarian constitutional reasoning. Quotations from previous decisions of the Constitutional Court citing the ECtHR judgements confirm this allegation, and it seems as if the Court attributed the same decisive role to the ECtHR judgements as to its own case law. ${ }^{57}$

51 | The annulment of a judicial decision is not suitable to remedy the excessive length of the procedure.

52 | There were no shortcomings discovered in the challenged decisions concerning the statements of reasons.

53 In proceedings aimed at the review of a judicial decision defined in Section 27, the Constitutional Court may also carry out the examination of the conformity of the legal regulation with the Fundamental Law as described in Section 26.

54 | Decisions 3/2013. (II. 14.), 30/2015. (X.15.),13/2016. (VII. 18.) of the Constitutional Court.

55 | E.g. Bukta and others v Hungary, Application no. 25691/04, judgement of 17 July 2007; Sáska v Hungary, Application no. 58050/08, judgement of 27 November 2012; Patyi and others v Hungary, Application no. 5529/05, judgement of 17 January 2012.

56 | Bukta and others v Hungary, Application no. 25691/04, judgement of 17 July 2007.

57 | The judge rapporteur of the freedom of assembly cases was Justice Sulyok, the president of the Constitutional Court. He (or the legal counsel preparing the drafts) often refers to the case law of the ECtHR by quoting previous decisions of the Constitutional Court. 
However, following the path set by the ECtHR is not always smooth. In Decision 13/2016. (VII. 18.) of the Constitutional Court, the Court repeated its own recent case law (without any reference to the ECtHR judgements) and argued against the correctness of the reasoning of the challenged judicial decision which upheld the police decision prohibiting a peaceful demonstration in front of particular family houses. The organisers planned a so called 'dynamic' assembly (series of demonstrations) where the participants would walk from site to site, stop there for a while (about 10 minutes), and listen to speeches. The prohibition affected only two of these places, one of which was the Prime Minister's residence. The Constitutional Court referred to its precedents under which a distinction is made between grounds for (preliminary) prohibition and grounds for dissolution of a demonstration, and a ground for dissolution may not be transformed automatically to a ground for dissolution. The grounds for prohibition can be laid down in an Act of Parliament in accordance with the fundamental right test; these grounds are exhaustively listed in the Assembly Act. In the challenged judicial decision, the Court stated that a peaceful demonstration can be banned under the general provisions of the Assembly Act ${ }^{58}$, recognising a clash between the right of assembly and the right to privacy. The dogmatic interpretation should have led to the annulment of the judicial decision; ${ }^{59}$ nevertheless, the Court rejected the complaint because the right to peaceful assembly was not overall disproportionately limited considering the fact that the participants could hold the assembly and set out their views in other sites. ${ }^{60}$ This argument was entirely new, not supported by any sources, and not deliberated in greater detail. It is not clear whether the Court only wanted to solve this case with special attention to the Prime Minister's residence or whether this conclusion was a result of a deeper consideration not reflected in the reasoning. In the same decision, the Constitutional Court ruled that the Parliament should enact appropriate legislation by the end of 2016 to assist the police and courts in cases of conflict between the right of assembly and the right to privacy. ${ }^{61}$

\subsubsection{Tacit objection to the ECtHR case law}

Decision 3064/2016. (IV. 11.) of the Constitutional Court is an example of tacit resistance to the adoption of the ECtHR case law.

The facts of the underlying case are as follows. The tax authority levied additional personal income tax, tax surcharges, and interest on the petitioner. The tax estimate of the tax authority was the ground for this decision. The burden of proof laid, statutorily, with the applicant to prove, providing credible evidence, the origin of the amount. Although the complainant alleged that they received a large loan from his mother and produced the written loan contract signed by both parties and two witnesses, and his

58 | To exercise the right of assembly must not infringe the rights and freedoms of others.

59 | See Decision 14/2016. (VII. 18.) of the Constitutional Court.

60 | A summary of the case can be read in English in the website of the Constitutional Court. It says, 'The Constitutional Court held that the protestors' constitutional right to freedom of assembly was not violated but, rather, lawfully curtailed by the police, because holding the demonstration would have interfered with the rights and freedoms of others (namely the Prime Minister). The Court noted that demonstrations could be held at other sites apart from the banned premises. The Court decision in question was not unconstitutional.' The different interpretation of the same reasoning (i.e. the one published in the website and that of the author of the present paper above) might derive from the unclear wording of the reasoning.

61 | See in relation to this issue: Hajas, 2016, p. 513-515. 
mother gave a testimony confirming that the loan was granted, these were not enough to rebut the estimate. On the action brought by the complainant, the court of first instance set aside the final administrative decision and obliged the tax authority to conduct a new procedure. The court held an on-site oral hearing and found the complainant's allegations convincing. In the revision in law procedure, the Curia, citing its case law and finding that the plaintiff did not provide credible evidence in accordance with the rules, set aside the first instance judgement and rejected the claim.

In the constitutional complaint, the petitioner argued that his right to a fair trial was violated because the Curia did not hold an oral hearing in the revision in law procedure. The complainant made a reference to the case of Pákozdi v Hungary. ${ }^{62}$ This judgement was delivered in a similar manner. The ECtHR did not attach decisive importance to the fact that the applicant did not request a hearing, but proceeded to an independent evaluation of the question of overall fairness of the proceedings, having the requirements of Art. 6 as the point of reference and held that there was a violation.

Neither did the Constitutional Court follow the reasoning of the Pákozdi judgement, nor did it make an attempt to refute the correctness thereof. The Court based its argumentation on its previous decisions, the rules of the Code of Civil Procedure (the party to an action has the right to request the Curia to hold an oral hearing in a revision in law procedure and this request may not be rejected), and the general principle pervading the Hungarian legal system that no one can rely on their own fault for gains. Rejecting the constitutional complaint, the Court indicated to the Curia that it is expedient to hold an oral hearing in similar cases, even if the party has not requested it. This recommendation was disapproved in concurring reasoning. ${ }^{63}$

It is salient that there is no reference to the 'minimum standard' requirement and the ECtHR judgement does not appear in the constitutional reasoning in a case which shows so much resemblance to the one forming the base of the ECtHR judgement. ${ }^{64}$ This solution might stem from the denial of the 'minimum standard' requirement, without the intention to convince the members of the body of the incorrectness thereof. Contrary to one of the concurring reasoning ${ }^{65}$, the majority did not consider it necessary to distinguish the case before the Constitutional Court from the Pákozdi case.

\subsection{Other ECtHR judgements in the constitutional reasoning of the Constitutional Court}

Even in the Constitutional Court's decisions invoking an ECtHR judgement delivered in a Hungarian case, one can find references to other ECtHR judgements, while other decisions contain references only to non-Hungarian cases.

62 | Application no. 51269/07, judgement of 25 November 2014.

63 Justice Sulyok found this 'indication' to the Curia unnecessary and stressed that the Curia itself decides whether it holds a hearing or not if no request has been filed by the parties, and the Curia certainly would consider the ECtHR judgement delivered in the Pákozdi case in similar cases. In his opinion, this indication was incapable of replacing the necessity to distinguish the present case from the Pákozdi case. He emphasised that under the case law of the ECtHR and the Pákozdi case, it can be judged only on case-by-case basis and on the basis of careful consideration of the circumstances whether the lack of an oral hearing leads to the violation of the right to fair hearing. $64 \mid$ The justice rapporteur of this case was Justice Pokol.

65 | See Justice Sulyok's concurring reasoning. Nevertheless, Justice Sulyok did not distinguish the present case from the Pákozdi case. 


\subsubsection{Dogmatic considerations}

The ECtHR, on the one hand, considers the particularities of the given matter in each case and, on the other hand, often lays down general principles for future application. ${ }^{66}$ It often occurs that what is relevant to the Constitutional Court ${ }^{67}$ is not the final outcome of the case but these general considerations. This is reflected especially in the selection ${ }^{68}$ of the so-called leading ${ }^{69}$ cases or the references to not only one but several ECtHR judgements, e.g. in Decision 37/2017. (XII. 11.) of the Constitutional Court dealing with a press report on a politician's news conference (the press cited word by word what had been said in the conference), the Court put as follows: some important aspects can also be drawn from the case law of the ECtHR in cases with different facts regarding the responsibility of the press reporting on public information and public events. The Court then quoted relevant general statements from several ECtHR judgements. In Decision of 7/2014. (III. 7.) of the Constitutional Court, it first repeated the 'minimum standard' requirement and subsequently referred to several ECtHR judgements. This shows that the Court is willing to accept the European case law as a guideline, and adjusts its own to it.

Reception of the ECtHR dogmatic systems to Hungarian constitutional reasoning occurs especially in relation to the freedom of expression, freedom of assembly (but see the decisions above referring to Hungarian cases), and the ne bis in idem principle. Many dogmatic considerations had already been adopted from the ECtHR case law before the Fundamental Law entered into force. These now form a part of the Constitutional Court's own precedents. ${ }^{70}$

In some decisions, the Constitutional Court refers only to one ECtHR judgement to underpin its reasoning; e.g. to include the shares of a company in the term 'property'71, to imply pouring paint on statues in the scope of freedom of expression ${ }^{72}$, and to explore the acceptability of a preliminary voter registration ${ }^{73}$. The final outcome of the cases was irrelevant; only certain aspect(s) of the facts and certain conclusions of the ECtHR played a role in the argumentation.

\subsubsection{When the violation of different fundamental rights is examined by the ECtHR and} the Constitutional Court

The Constitutional Court appears to be open to referring to an ECtHR judgement even when the latter is based on another fundamental right than the one the violation of which is examined by the Constitutional Court.

66 | E.g. see: Gerards, 2017, p. 266.

67 | Nevertheless, one can find decisions in which the Constitutional Court concentrated on the particular circumstances and the outcome of the cases before the ECtHR to explore what violated the fundamental rights and what did not. E.g. Decision 7/2019. (III. 22.) of the Constitutional Court 68 | E.g. Decisions 38/2012. (XI. 14.), 34/2017. (XII. 11.), 7/2014. (III. 7.), 36/2014. (XII. 18.), 33/2013. (XI. 22.), 8/2017. (IV.18.) of the Constitutional Court

69 | E.g. case of Engel and others v the Netherlands, No. 5370/72, judgement of 8 June 1976; case of Öztürk v Germany, No. 8544/79, judgement of 23 October 1984; case of A and B v Norway, No. 24130/11 and 29758/11, judgement of 15 November 2016

70 | Right to fair trial could also be mentioned in this list; however, the selected 30 decisions do not reflect it.

71 | Decision 20/2014. (VII. 3.) of the Constitutional Court

72 | Decision 1/2019. (II. 13.) of the Constitutional Court

73 | Decision 1/2013. (I. 7.) of the Constitutional Court 
This is usually derived from a different list of fundamental rights in the ECHR and the Fundamental Law.

The Fundamental Law guarantees, e.g. the right to inheritance as a separate fundamental right. In Decision 5/2016. (III.1.) of the Constitutional Court ${ }^{74}$, the Court, 'reviewing' the case law of the ECtHR, referred to the case of Marckx v Belgium ${ }^{75}$ in which the ECtHR examined whether Art. 1 of Protocol No. 1 was violated by the Belgian rules restricting the 'illegitimate' child's right to inheritance after their mother and the mother's right to bequeath to her 'illegitimate' child the whole or a part of her property. The ECtHR held that Art. 1 of Protocol No. 1 was not applicable to the child, while it was applicable to her mother; nevertheless, no violation of the right to property was found, taken alone. The European court also held that there was a breach of Art. 14 of the ECHT taken in conjunction with Art. 1 of Protocol No. 1 with respect to the mother. Only this latter outcome was highlighted in the Constitutional Court's decision, and no reference to the first two results was made.

The Constitutional Court paid attention to the fact that in the Fundamental Law and the constitutions of some EU member states, the right to inheritance can be found in the same provision as the right to property. It did not work out what the complainant as the beneficiary of a will was entitled to under the fundamental right to inheritance (passive side); instead, it founded its reasoning on the violation of the deceased's (testator's) rights to property (active side) and declared unconstitutional the challenged judicial decision not to acknowledge the testator's right to bequeath usufruct by his will.

The ECtHR judgement was an illustration of the close relationship between the right to inheritance and the right to property, notwithstanding that the European forum rejected the application of the daughter as successor under Art. 1 Protocol No. 1 and found no violation on the mother's side, taken alone. ${ }^{76}$

The ECHR does not guarantee the right to human dignity, the Fundamental Law does, and the Constitutional Court adopted the case law of the German Constitutional Court on the right to self-determination and the general personality right. Thus, the same issue relates to different fundamental rights under the European regime and the Hungarian constitutional law. For example, specific questions concerning the legal recognition of gender ${ }^{77}$ or the publication of photos taken of persons (i.e. policemen in action) in the press $^{78}$ come under the right to privacy (Art. 8) as guaranteed by the ECHR and human dignity ensured by the Fundamental Law. ${ }^{79}$

The Fundamental Law guarantees the right to access and disseminate data of public interest. The right to access data of public interest has been deduced from the freedom of expression under the ECHR, as elaborated, especially in the case of Magyar Helsinki Bizottság v Hungary ${ }^{80}$. Although it can be qualified as a leading case of the ECtHR, the reference to this judgement in Decision 13/2019. (IV. 8.) of the Constitutional Court did not have relevance in this regard. The method of reference in the above-mentioned decision

74 | The petitioner complained that the court dismissed its claim on the ground that the testator was not entitled to bequeath usufruct to anyone, since the testator encumbered the property for a period after his death by this act; therefore, he was not the owner thereof.

75 | Marckx v Belgium, Application no. 6833/74, judgement of 13 June 1979

76 | The judge rapporteur of this decision was Justice Pokol.

77| See Decision 6/2018. (VI. 27.) of the Constitutional Court

78 | See Decision 28/2014. (IX. 29.) of the Constitutional Court

79 | See: Zakariás, 2017, pp. 108-114.

80 | Application no. 18030/11, judgement of 8 November 2016 
to several ECtHR judgements, namely using 'cf.', make an impression that the Court applied the ECtHR case law to confirm its own conclusions.

The above-mentioned cases fall formally in part outside the 'minimum standard' requirement, as the Fundamental Law defines the essence of the fundamental rights differently from the international treaty (e.g. right to inheritance). In other cases, the same fundamental right is guaranteed by the Fundamental Law and the ECHR (i.e. right to privacy); nevertheless, certain situations dogmatically belong to the scope of another right (i.e. human dignity) in the Hungarian legal system. References to the ECtHR case law have an illustrative role rather than confirming in the strict sense or being decisive, and demonstrate that the Constitutional Court is aware of the European trends.

\section{Some other minor curiosities}

Taking the 30 decisions of the Hungarian forum containing references to the ECtHR judgements delivered either in a Hungarian or foreign case, one can conclude that the Constitutional Court applies the European jurisprudence quite flexibly. There are three decisions in which the Constitutional Court carried out an examination on the basis of other provisions of the Fundamental Law than fundamental rights. In Decision 22/2016. (XII. 5.) of the Constitutional Court delivered in the abstract interpretation of Art. E) (2) ${ }^{81}$, the Court stipulated that the Constitutional Court can examine whether the joint exercise of competences with the European Union infringes human dignity, other fundamental rights, the sovereignty of Hungary, or Hungary's self-identity based on its historical constitution. This decision developed the Court's fundamental rights-reservation review and ultra vires review (composed of a sovereignty review and review based on constitutional identity). ${ }^{82}$ The resolution generally concerns fundamental rights, and the Court strengthened the reasoning by referring to the case of Matthews v the United Kingdom ${ }^{83}$. It is made not by citing a particular section of the statement of reasons, but by summing up what the Constitutional Court read out from the judgement as a conclusion: a member state of the EU, relying on the enforcement of the EU law, may not be absolved of responsibility before the ECtHR.

In Decision 2/2019. (III. 5.) of the Constitutional Court, interpreting the provisions of the Fundamental Law in an abstract way, the Court relied on the case of Kiss Alajos $\mathrm{v}$ Hungary ${ }^{84}$ to demonstrate that the international principle of pacta sund servanda is capable of overriding even national constitutions and, therefore, the international legal obligations shall be complied with in all cases.

81 | 'With a view to participating in the European Union as a Member State and on the basis of an international treaty, Hungary may, to the extent necessary to exercise the rights and fulfil the obligations deriving from the Founding Treaties, exercise some of its competences arising from the Fundamental Law jointly with other Member States, through the institutions of the European Union. Exercise of competences under this paragraph shall comply with the fundamental rights and freedoms provided for in the Fundamental Law and shall not limit the inalienable right of Hungary to determine its territorial unity, population, form of government and state structure.'

82 | See: Drinóczi, 2017.

83 | Application no. 24833/94, judgement of 18 February 1999

84 | Application no. 38832/06, judgement of 20 May 2010 
The Court referred to the case of Tătar v Romania ${ }^{85}$ in Decision 28/2017. (X. 25.) of the Constitutional Court in relation to the principle of precaution. Although the posterior norm control was carried out on the basis of Art. P) of the Fundamental Law on environment protection, the Court felt necessary to emphasise that this principle was recognised not only in national, but also international law and case law.

\section{Final remarks}

As can be seen on the basis of the analysis of the 30 decisions, the Constitutional Court uses the ECtHR jurisprudence in its constitutional reasoning in a quite multicoloured and flexible way. Even when the ECtHR judgements have a very loose connection with the subject matter of the case before the Constitutional Court, it is not reluctant to rely on them. Although the ECtHR judgements should have an illustrative rather than confirming role in those cases, it seems that the Court strives to strengthen its reasoning by these references. Only a closer look and further investigation can reveal that the substantive relation is missing between the constitutional issue and the judgement referred to. In the statement of reasons, this remote connection might remain invisible. Nevertheless, it shows that the Constitutional Court attributes a certain level of authority to the ECtHR judgements or respects them as guidelines in the interpretation of the Fundamental Law. It considers the Strasbourg case law as a source capable of confirming the Constitutional Court's conclusions, thus persuading the readers of the correctness of those conclusions.

Reference to the ECtHR judgements in the decisions of the Constitutional Court can be seen as a revelation of the intent to be part of the European community of states. In this regard, it is usually not the particularities of a case which has significance, but the general findings of the Court. The Constitutional Court has proved to be open to adopting dogmatic considerations from the ECtHR jurisprudence. Reception had already taken place before the Fundamental Law entered into force, and it is still an ongoing process. A large body of dogmatic considerations has become a part of the Hungarian constitutional law, which is reaffirmed case by case by the Constitutional Court. Deviating from these dogmatic considerations consistently and to a large extent would result in questioning the values formulated in the ECHR.

Nevertheless, the reception does not necessarily entail the acknowledgement of the binding effect of the ECtHR judgements on the Constitutional Court. ${ }^{86}$ Although the 'minimum standard' requirement accepts, on legal basis, the outstanding and, to some extent (i.e. no lower level of protection is permitted), definitive role of the ECtHR jurisprudence in the interpretation of the Fundamental Law, what obligation derives therefrom and what qualifies a 'level of legal protection provided by the international legal protection mechanism' have not been elaborated in detail. Moreover, it is not consistently applied or, at least, referred to, and some justices heavily object it. It would be useful to 
distinguish between the particular judgements and the principles crystallised in the ECtHR case law. ${ }^{87}$

Looking at the selected decisions, the impression is that the Constitutional Court prefers being silent as for the reasons of deviations (avoiding any reference to the relevant ECtHR judgements or selecting the judgements arbitrarily) to openly confront the ECtHR judgements. This hides whether theoretical considerations are behind this behaviour or particular interests. As can be seen from the analyses, the Court sometimes selects the ECtHR judgements arbitrarily ${ }^{88}$ and quotes the findings only in part; thus, relevant developments of the European case law or important aspects of cases might remain in the background. This attitude can contribute to unpredictable decisions and creates the image that the ruling stood first, and the reasons came second. 


\section{Bibliography}

Blutman, L. (2009) 'A nemzetközi jog használata az Alkotmány értelmezésénél', Jogtudományi Közlöny, 2009/7-8, pp. 301-315.

Bragyova, A. (2011) 'Az értelmezés hatalma', Alkotmánybírósági Szemle, 2011/1, pp. 83-92.

Chronowski, N. 'A Magyar alkotmánybíráskodás és a közös európai alkotmányos standardok', Jura, 2014/2, pp. 26-38.

Drinóczi, T. (2017) 'A 22/2016 (XII. 5.) AB határozat: mit (nem) tartalmaz, és mi következik belőle - Az identitásvizsgálat és az ultra vires közös hatáskörgyakorlás összehasonlító elemzésben', MTA Law Working Papers, 2017/1. [online]. Available at: http://real.mtak.hu/121486/1/2017_01_Drinoczi.pdf (Accessed 28 September 2021).

Gerards, J. (2017) 'The European Court of Human Rights' in Jakab, A., Dyevre, A., Itzcovich, G. (eds.) Comparative constitutional reasoning. Cambridge, Cambridge University Press.

Hajas, B. (2016) ‘A gyülekezési jog korlátainak elméleti kérdéseiről és bírósági gyakorlatáról', Magyar Jog, 2016/9, pp. 511-524.

Jakab, A., Fröhlich, J. (2017) 'Constitutional Court of Hungary' in Jakab, A., Dyevre, A., Itzcovich, G. (eds.) Comparative constitutional reasoning. Cambridge: Cambridge University Press.

Kovács, P. (2013) ‘Az Emberi Jogok Európai Bírósága ítéletére való hivatkozás újabb formulái és technikái a magyar Alkotmánybíróság, valamint néhány más európai alkotmánybíróság mai gyakorlatában', Alkotmánybírósági Szemle, 2013/2, pp. 73-84.

Kovács, P. (2020) 'Az Emberi Jogok Európai Bíróságára és más nemzetközi egyezményekre való hivatkozás az Alkotmánybíróságon és a Nemzetközi Büntetőbíróságon: hasonlóságok és különbségek', Miskolci Jogi Szemle, 15 (1) Special edition, 145-153.

Köblös, A. (2021) 'Interpretation of Fundamental Rights in Hungary' in Tóth, J. Z. (ed.) Constitutional Reasoning and Constitutional Interpretation. Budapest - Miskolc: Ferenc Mádl Institute of Comparative Law - Central European Academic Publishing.

Sándor, L. (2020a) 'Az Alkotmánybíróság és az Emberi Jogok Európai Bírósága előtt ugyanazon közhatalmi aktus ellen benyújtott panaszok miatt indult jogvédelmi ügyek összehasonlító értékelése', Alkotmánybírósági Szemle, 2020/1, pp. 31-36.

Sándor, L. (2020b) 'Az Alkotmánybíróság és az Emberi Jogok Európai Bírósága előtt ugyanazon közhatalmi aktus ellen benyújtott panaszok miatt indult jogvédelmi ügyek összehasonlító értékelése' Part 2, Alkotmánybírósági Szemle, 2020/2, pp. 30-37.

I Szente, Z (2013a) Érvelés és értelmezés az alkotmányjogban. Budapest: Dialóg Campus.

Szente, Z. (2013b) 'The interpretative practice of the Hungarian Constitutional Court - A critical view', German Law Journal, 2013/8, pp.1591-1614. 
Téglási, A. (2011) A tulajdonhoz való jog alkotmányos védelme, PhD Thesis [Online]. Available at: http://doktori.bibl.u-szeged.hu/id/eprint/783/1/A_tulajdonhoz_ val\%C3\%B3_jog_alkotm\%C3\%A1nyos_v\%C3\%A9delme_2011.01.14.(NYILV. VIT\%C3\%81RA_LEADOTT).pdf (Accessed: 30 August 2021)

Téglási, A. (2012) 'A tulajdon védelme Magyarország Alaptörvényében különös tekintettel az alkotmánybírósági gyakorlat lehetséges változásaira', Alkotmánybírósági Szemle, 2012/2, pp. 116-125.

Uitz, R. (2016) ‘Nemzetközi Emberi jogok és a magyar jogrend’ in Jakab, A., Gajduschek, Gy. (eds.) A magyar jogrendszer állapota, MTA Társadalomtudományi Kutatóközpont, Jogtudományi Intézet [online] Available at: (https://jog.tk.hu/uploads/files/08_Uitz_ Renata.pdf (Accessed: 30 August 2021).

Zakariás, K. (2017) 'A képmáshoz való alapjog. A bírói döntések alkotmánybírósági felülvizsgálatának terjedelme', Alkotmánybírósági Szemle, 2017/2, pp. 108-114. 